\title{
INFLUENCE OF REST BREATHING FREQUENCIES ON THE PARAMETERS OF HEART RATE VARIABILITY TACHOGRAPHS
}

\author{
WPEYW CZESTOTLIWOŚCI ODDYCHANIA SPOCZYNKOWEGO \\ NA PARAMETRY TACHOGRAFÓW ZMIENNOŚCI RYTMU SERCA
}

\author{
${ }^{1}$ Department of Ecology and Environmental Protection, Nicolaus Copernicus University in Toruń, \\ Collegium Medicum in Bydgoszcz \\ ${ }^{2}$ Department of Biotechnology, University of Zielona Góra, Faculty of Biological Sciences \\ ${ }^{4}$ Department of Biochemistry, Nicolaus Copernicus University in Torun, Collegium Medicum in Bydgoszcz
}

S u m m a r y

The relaxation response is a method of overcoming stress factors. It is activated through slow breathing, which causes high heart rate variability. Higher heart rate variability increases the activity of parasympathetic nervous system causing organism to relax. The relaxation response is activated, when human organism achieves a state of inner balance, which is called the coherence. One of techniques to achieve this state of balance is breathing in the specific rhythm, which is usually around $0.1 \mathrm{~Hz}$ of frequency. This value is called the resonance frequency. In this study the activity of central nervous system in the specific range of breathing frequencies $(0.07-0.12 \mathrm{~Hz})$ has been checked in order to find an answer, if the relaxation response is triggered by one specific frequency or is there a specific range of breathing frequencies, which lead to the state of inner balance. In order to check the changes throughout human body the heart rate assessed by biofeedback technique has been used. It is a non-invasive method examining the function of sympathetic and parasympathetic nervous system through the changes in natural heart rhythm. Throughout the biofeedback sessions the resonance frequency is measured. The aim of this study was to check if there is a difficulty for subjects to maintain imposed breathing rhythm and if there is only one universal resonance frequency for everyone or is there a specified range. The study confirmed the difficulty of maintaining unnatural breathing frequency. It has also showed that there is a specific range of frequency values which can be used to achieve the coherence state.

\section{Streszczenie}

Odpowiedź relaksacyjna, to sposób walki ze stresem; wiąże się ze spokojniejszym oddychaniem, które powoduje wysoką zmienność rytmu serca, w efekcie czego wzrasta aktywność parasympatycznego układu nerwowego PUN, powodując wyciszenie organizmu. Odpowiedź ta jest wyzwalana w momencie wprowadzenia organizmu w stan wewnętrznej równowagi, określany mianem koherencji. Jedną $\mathrm{z}$ technik osiągnięcia stanu równowagi jest oddychanie zgodne z rytmem częstotliwości rezonansowej, która przeciętnie wynosi $0.1 \mathrm{~Hz}$. W tych badaniach sprawdzono zachowanie ośrodkowego układu nerwowego OUN w przedziale częstotliwości $0,07-0,12 \mathrm{~Hz}$ celem sprawdzenia, czy odpowiedź relaksacyjna RR dotyczy tylko jednej specyficznej częstotliwości, czy też istnieje tolerancja częstotliwości oddychania wywołująca tożsame odpowiedzi organizmu. Aby zbadać zmiany zachodzące $\mathrm{w}$ organizmie, posłużono się tzw. metodą biofeedback HRV. Jest to metoda nieinwazyjna, badająca poprzez zmiany rytmu serca działanie sympatycznego układu nerwowego SUN i PUN. Na takich sesjach mierzy się częstotliwość rezonansową, aby instruować uczestników - jak kierować oddechem w celu utrzymania pożądanego tempa oddychania. Analizowano sensowność utrzymywania konkretnego rytmu. Badano również, czy istnieje trudność w dostosowaniu własnego oddechu do wymaganego tempa. Badania potwierdziły problem wynikający z utrzymania sugerowanego rytmu oddychania. Wykazano również, że istnieje zakres rytmu wentylacji 
pozwalający uzyskać efekty podobne, jak podczas oddychania w tempie rezonansowym.

Key words: heart rate variability, HRV biofeedback, resonance frequency, relaxation response, coherence Slowa kluczowe: zmienność rytmu serca, biofeedback HRV, częstotliwość rezonansowa, odpowiedź relaksacyjna, koherencja

\section{INTRODUCTION}

The relaxation response $R R$ is defined as a physiological state of organism which decreases the stimulation of sympathetic nervous system SNS. RR is currently considered as the key ability of conscious stress auto-control. The methods of activating RR are based on the specific breathing techniques [1], causing high heart rate variability, which affects the increased activity of parasympathetic nervous system PNS achieving the RR [2]. The coherence is called the inner balance, welfare, unity and integrity of human organism [3]. Getting into the coherence state causes the RR leading to calming the body and normalization of physiological processes. The RR effects in stabilization of both pathways of autonomic nervous system ANS.

The resonance frequency is considered as the rhythm of around 6 breaths per minute, i.e. around 0.10 $\mathrm{Hz}$ [4]. A subject breaths according to the resonance frequency of the heart rhythm HR, blood pressure BP and the rhythm of ventilation overlap. It has been showed that during the long inspiration (ongoing for 5 seconds), the extension of chest stimulates heart to increase its rhythm. At the same time low BP affects baro-receptors which send an impulse in order to raise the HR. The signal from SNS also effects increase of heart action. During the long exhale there is the reverse situation. Decreasing the volume of chest increases BP, affects baro-receptors and causes PNS to send a signal affecting HR decreasing. This explains why during the breathing with resonance frequency the HR amplitude is highest $[5,6]$. The perfect synchronization of this system creates conditions to achieve the state of physiological coherence [3, 7]. It has also been showed that the frequency resonance can be different in various individuals [4]. According to the results given by [8], the average value of frequency resonance is $0.1 \mathrm{~Hz}$. It has also been showed that this value depends on the height and sex but there is no dependency on changes of body weight [9].

The biofeedback is a non-invasive method which lets the participants to observe the state of their coherence during the session and lets them consciously affect their breathing rhythm. Thanks to this facilitation, achieving RR is faster and more effective [7]. The heart rate variability HRV determined by biofeedback method has been used in this study. The HRV biofeedback captures the changes in heart rhythm, which reflects (based upon tachograph analysis) the cooperation of SNS and PNS [10]. The correlation between HRV and BP is inversely proportional [11]. The lower the HRV amplitude is, the higher BP becomes. Thanks to this phenomenon, during the R-R section of EKG tachograph, it is possible to measure the fact of achieving the coherence state and tracking the behaviour of entire body.

The $\mathrm{HF}_{\mathrm{N}}$ parameter is a power of high band frequencies in range of $0.15-0.4 \mathrm{~Hz}$, obtained thanks to fast Fourier transformation FFT, expressed in the normalized units [12]. A higher value of this parameter causes the lower coherence. The subject who tries to achieve RR is slowing the breath, which is showed as a low frequency bands on HRV tachograph. On the other hand, the increased ventilation ratio, i.e., during excitation, expresses in the high frequency bands on tachograph, which increases the complexity of measurement [2]. It causes incoherence by increasing both HR and BP, preventing subjects from achieving the state of relaxation. [13].

The HF parameter reflects the absolute value of high frequency bands summing their participation in entire HRV record. It is obtained by the FFT method and expressed in $\mathrm{ms}^{2}$ [12]. HF is an indicator of the functioning of PNS. The reference values for this parameter are $975 \pm 203\left(\mathrm{~ms}^{2}\right)$ [14]. The higher the HF value is the lower coherence we observed [3].

Shannon's Entropy or statistical entropy ShEN reflects the organization of micro-measurements of R$\mathrm{R}$ sections. The more chaotic heart rate, the more stimulated the SNS. When the EKG record is more complex, ShEN values become higher [15]. Heart rhythm is more stable in the coherence state the R-R sections are more regular which affects in lowering the entropy. This parameter allows evaluation of SNS and PNS activity [12]. 


\section{THE AIM OF STUDIES}

The aim of this study was to check if there is a difficulty for subjects to maintain imposed breathing rhythm and if there is only one universal resonance frequency for everyone or is it some specified range.

\section{MATERIAL AND METHODS}

42 healthy adults, aged 20-51-years took part voluntarily in this study. Each participant was assigned to one of six computer stations. Every test-bench was equipped with a table, chair, headphones, laptop, and an ear lobe pulse sensor. This device measured HRV by monitoring the changes in blood flow through the ear lobe blood vessels. Before starting the measurement the subjects were taught how to use the emWave Desktop PC software. The software was used to note the heart rate of the participants. Subjects were to launch the audio program, which contained the instructions for rest breathing, and emWave Desktop PC. Subject observed the graphical feedback on the monitor. Program shows real-time heart rate value and a level of coherence, which lets participants to change rate of the breathing and indirectly modify heart rate. In this study each participant provided 32 minutes of heart rate variability recording. We used 190 measurements. Each session consisted of 8 parts; in the first one, subjects relaxed and in the last one they prepared to normal activity. These fragments were removed for further analysis. The remaining six parts were taken to analysis. Every part had 3 minutes length. In this fragments the frequency of metronome, which showed the rhythm of breathing for participants, was about 0.07-0.12 Hz.

All results were collected on a computer disk and memory cards. Each measurement was recorded as a $\mathrm{xml}$ file and saved in the folder consisting of the data set for further processing in accordance with the adopted coding system. Data were converted in MS Excel 2007 and analyzed by Kubios HRV 2.0 prg. This program divided each measurement into 8 fragments. We obtained 6 files and sorted them by mean rate of the frequency of the metronome. We calculated 53 parameters in MS Excel 2007 for each file. The next step was the factor analysis in Statistica v.10.0, Statsoft, Pl. During the assay, varimax normalized rotation has been used and we obtained statistically significant parameters. Afterwards, the Kaiser criterion was used and to other calculations those factors, whose value was equal to 1 or even greater were used. The statistical significance of the results was calculated by using student T-test. Each parameter value used in specific frequency was compared with values from 0.1 Hz. Each p-value showed the statistical homogeneity of the group.

Information about the respiration rate was obtained from one of 53 parameters, which represented the dominant frequency in HRV. Measurements were divided into groups according to the degree of noncompliance with the frequency of the metronome.

\section{RESULTS}

Only the measurements, which degree of noncompliance with the frequency of the metronome were not higher than $30 \%$ were used. The data was divided into 3 sections. First set was created from data, which degree of non-compliance was not higher than $10 \%$. Groups of $10-20 \%$ and of $20-30 \%$ showed the changes of the parameters, whilst respiration frequency was not the same as the rhythm of the metronome. Table I presents the percentage values of measurements, which were inside the criteria of acceptance. Results show that the majority of subjects $(65.1 \%)$ was in the group of $10 \%$ degree of non-compliance with timing of the metronome for the frequency $0.1 \mathrm{~Hz}$. The group of fewest subject $(39.9 \%)$ was of $30 \%$ of degree of noncompliance with the frequency of the metronome of $0.07 \mathrm{~Hz}$. Similar trends were obtained for groups of $20 \%$ and of $30 \%$ degree of non-compliance with the frequency of the metronome.

Table I. The percentage of measurements within $10 \%$ and $30 \%$ of degree of non-compliance with timing of the metronome.

\begin{tabular}{|l|c|c|c|c|c|c|c|c|c|c|c|c|}
\hline $\begin{array}{l}\text { The } \\
\text { frequency } \\
\text { of the } \\
\text { metronome } \\
{[\mathrm{Hz}]}\end{array}$ & \multicolumn{2}{|c|}{0,12} & \multicolumn{2}{|c|}{0,11} & \multicolumn{2}{|c|}{0,1} & \multicolumn{2}{|c|}{0,09} & \multicolumn{2}{|c|}{0,08} & \multicolumn{2}{|c|}{0,07} \\
\hline $\begin{array}{l}\text { Margins of } \\
\text { tolerance }\end{array}$ & $10 \%$ & $30 \%$ & $10 \%$ & $30 \%$ & $10 \%$ & $30 \%$ & $10 \%$ & $30 \%$ & $10 \%$ & $30 \%$ & $10 \%$ & $30 \%$ \\
\hline $\begin{array}{l}\text { The } \\
\text { percentage of } \\
\text { measurements } \\
\text { within the } \\
\text { criteria of } \\
\text { acceptance } \\
{[\%]}\end{array}$ & 60 & 85 & 61 & 83 & 65 & 87 & 63 & 82 & 53 & 73 & 40 & 61 \\
\hline
\end{tabular}

The factor analysis isolated a few parameters with highest statistical value. There were described results concerning parameters $\mathrm{HF}_{\mathrm{N}}, \mathrm{HF}$ and ShEN in this paper. $\mathrm{P}$ values were showed on grey background (which had value $\leq 0.05$ ) indicating the statistical 
diversity of results. The values on white background (which had value > 0.05) show the statistical homogeneity of these results. Each graph and table was calculated to the statistical range of $10-30 \%$.

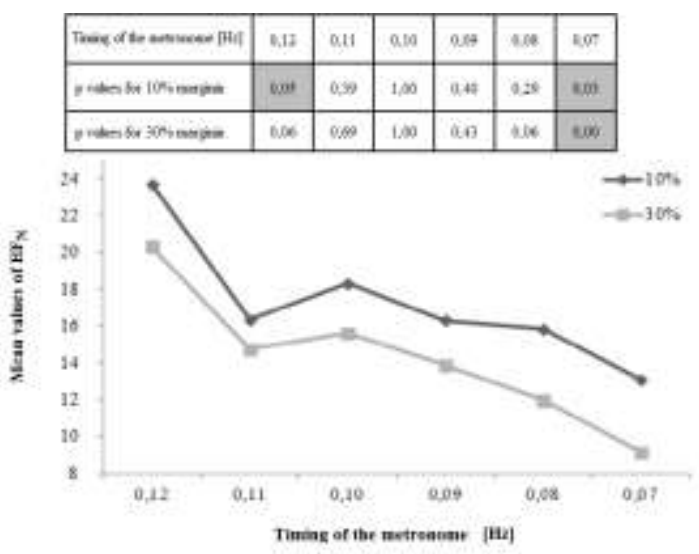

Fig. 1. Table and graph for the $H F_{N}$ parameter, the table contains the average values and p-value; the graph shows changes of the mean values

As Fig. 1 show, no significant changes were observed only for the frequencies of the metronome in the range of $0.11-0.08 \mathrm{~Hz}$, for $\mathrm{HF}_{\mathrm{N}}$ parameter. The results of $10 \%$ of margin of tolerance had 2-4 higher values than the group of $30 \%$. The margin of tolerance significantly affects $\mathrm{HF}_{\mathrm{N}}$ values. Margin of tolerance had no effect on the course of the graphs. Both of these graphs had the same trend. The results for frequency of $0.12 \mathrm{~Hz}$ had the highest values and the smallest were obtained for $0.07 \mathrm{~Hz}$ (Fig. 1).

\begin{tabular}{|c|c|c|c|c|c|c|}
\hline 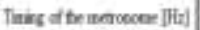 & 0.12 & $0.1 \mathrm{t}$ & 0.10 & 0,09 & 0,08 & 0,00 \\
\hline 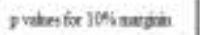 & $0: 38$ & $02 z$ & 100 & 064 & $2 \pi t$ & 0,28 \\
\hline 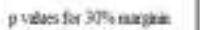 & 0,48 & 027 & $t \infty 0$ & 0,0 & 9,28 & 900 \\
\hline
\end{tabular}

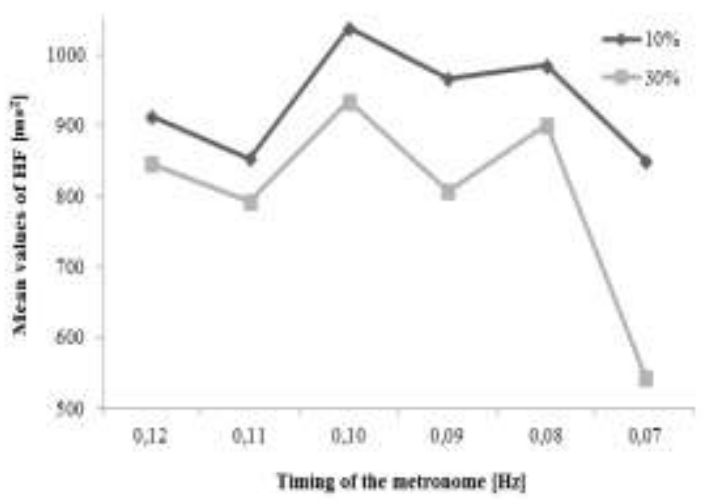

Fig. 2. Table and graph for the HF parameter, the table contains the p-values; the graph shows changes of the mean values
Significant changes for HF parameter were observed only for the frequency of the metronome in $0.07 \mathrm{~Hz}$ for $30 \%$ of the group, which shows table on Fig 2. For other frequencies changes was not significant. Graph in the same figure shows that results from $10 \%$ margin of tolerance had higher values than from $30 \%$ of the group. The margin of tolerance significantly affects HFN values. Margin of tolerance had no effect on the course of the graphs. Both of these graphs had the same trend. Results for frequencies of 0.10 and $0.08 \mathrm{~Hz}$ had the highest values and the smallest were obtained for $0.07 \mathrm{~Hz}$.

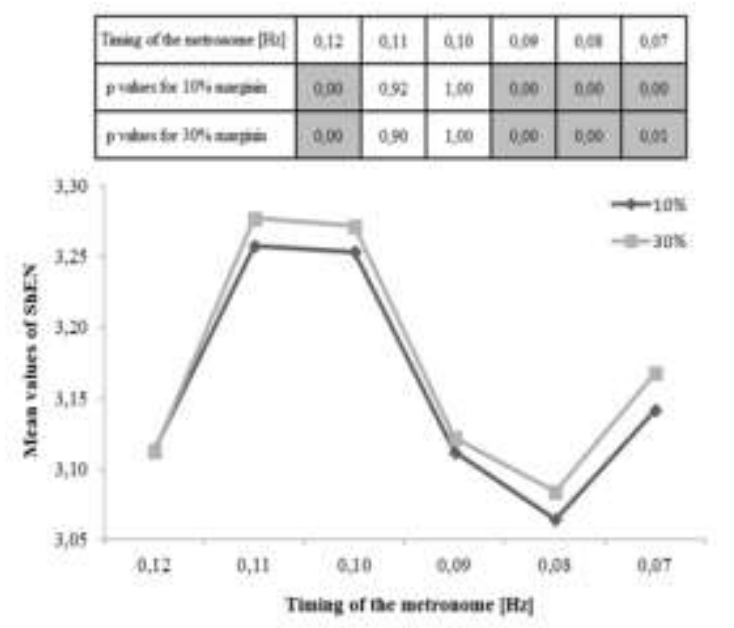

Fig. 3. The table and graph for the ShEN parameter, the table contains the p-values, the graph shows changes of the mean values

As Fig. 3 shows, no significant changes was observed for the frequencies of the metronome in range 0.11-0.10 Hz, for ShEN parameter. For other frequencies changes were statistically significant. Margin of tolerance had no significant effect on ShEN values and on the course of the graphs. Both of these graphs had the same trend. The results for the frequencies of $0.11,0.10$ and $0.07 \mathrm{~Hz}$ had the highest values and the smallest were obtained for 0.12, 0.09 and $0.08 \mathrm{~Hz}$.

\section{DISCUSSION}

Results in Table I show that the smallest percentage of participants (about $40 \%$ ) were able to maintain 0.07 $\mathrm{Hz}$ of respiration rate. The largest group of subjects (about $65 \%$ ) were able to maintain $0.1 \mathrm{~Hz}$ respiration rate. These results confirmed similar studies by [16] that maintaining of resonance frequency is troublesome 
for participants [16]. Factor analysis showed statistically significant parameters. There were presented changes in 3 parameters: $\mathrm{HF}_{\mathrm{N}}, \mathrm{HF}$ and ShEN. Figure 1 shows that it is not necessary to maintain rhythm ventilation within resonant frequency for changes in $\mathrm{HF}_{\mathrm{N}}$. Maintaining breathing rhythm in the range of $0.11-0.08 \mathrm{~Hz}$ brought similar results as breathing in resonance frequency. As Figure 1 shows, the slow breathing rate caused more regular heartbeat [13], which caused stronger RR and higher coherence [2].

HF results in Fig. 2 show no significant changes for the frequencies of the metronome for this parameter. Maintaining breathing rhythm in the range of 0.11-0.07 $\mathrm{Hz}$ brought similar results as breathing in $0.10 \mathrm{~Hz}$ of frequency. According to the current data, the normal values for $\mathrm{HF}$ are within the range of $975 \pm 203 \mathrm{~ms}^{2}$ [14]. Most of the values presented in the table in Fig. 2 were within the norm. The only exception was the result obtained during $0.07 \mathrm{~Hz}$ for $30 \%$ of the group of breathing rate, which was lower. For $10 \%$ of the group the lowest value was obtained for $0.11 \mathrm{~Hz}$, such a low value may indicate significant activity of PNS $[3,16]$. The highest values were obtained when breathing rhythm was about $0.10 \mathrm{~Hz}$ or $0.08 \mathrm{~Hz}$. It shows the activation of SNS, stimulation of the vagal nerve [16] and resulted in the reduced coherence. The studies by [3] from 2010 showed that the slower HRV rhythm causes more effective RR [3].

Results for ShEN were different. The highest values were obtained for the frequency of the metronome of $0.11,0.10$ and $0.07 \mathrm{~Hz}$. These values indicated the high irregularity of heart contractions at the rate of respiration [12, 15]. According to current information, the rhythm of $0.1 \mathrm{~Hz}$ should call RR and therefore, affect the regular heartbeat. In these studies, low values of Shannon entropy, corresponding to measured contractions of the myocardium and RR responses, were obtained for the rate of $0.08 \mathrm{~Hz}[12$, 15]. At this time there are neither specific standards for this parameter nor accurate investigation of its behaviour during breathing resonant frequency. The behaviour of the body during respiration at different frequencies with the specific behaviour of the body during ventilation in the rhythm of $0.10 \mathrm{~Hz}$ was compared. According to the data of Fig. 3, the range of 0.11-0.10 produces identical results to the resonant frequency.

The analysis of $\mathrm{HF}_{\mathrm{N}}$ and HF showed homogeneity of results for several central frequencies of the participants. Breathing in the rhythm of the range of $0.11-0.08 \mathrm{~Hz}$ induced the same effects as when ventilation according to the rhythm of the resonance. For these two parameters some regularities were observed in this range, i.e., that decrease in the breathing rate causes more regular heartbeat [13], more effective RR and higher coherence [2]. According to recent studies, breathing in these frequencies indicated rhythmic contractions of the heart and RR $[2,3,12,15$, 17, 18]. This confirmed previous results which showed organized and sinusoidal heart rate at frequencies close to $0.1 \mathrm{~Hz}$. Only ShEN results indicated that there are needed further research in this area and the introduction of relevant standards.

\section{CONCLUSIONS}

1. The calculations in this study allowed determining the average range with observed homogeneous values ranged from 0.11-0.08 Hz. This indicated that there is no need for measuring and maintaining the $\mathrm{f}$ ventilation at the rate of $0.10 \mathrm{~Hz}$ in healthy individuals.

2. The right breathing rhythm has been proved in the range of 0.11-0.08 Hz.

3. Our studies show difficulties of maintaining a suggested rate of breathing. In further studies the parameter ShEN should be checked for breathing in resonance rhythm.

\section{REFERENCES}

1. Telles S., Singh N., Joshi M., Balkrishna A., Post traumatic stress symptoms and heart hate variability In Bihar Floyd survivors following yoga: a randomized controlled study, BMC PSYCHIATRY 2011; 10:18

2. McCraty R., Atkinson M., Tomasino D., Bradley R. T., Emotions and heart rhythm patterns, Psychological Coherence, The Coherent Heart, Boulder Creek, California 2006; 7-14

3. McCraty R., Childre D., Coherence: Bridging personal, social and global health, ALTERN THER HEALTH M 2010; 16 (4) 10-24

4. Wanqing W., Yeongjoon G., Jungtae L., Combination of wearable multi-biosensor platform and resonance frequency training for stress management of the unemployed population, SENSORS 2012; 12 1322513248

5. Lehrer P., Applied psychophysiology: Beyond the boundaries of biofeedback (mending a Wall, a brie history od our field and applications to control of the muscles and cardiorespiratory systems), APPL PSYCHOPHYS BIOF 2003; 28 (4) 291-304 
6. Wheat A. L., Larkin K. T., Biofeedback of heart rate variability and related physiology: A critical review, APPL PSYCHOPHYS BIOF 2010; 35, 229-242

7. McCraty R. Tomasino D. Heart rythm coherence feedback: A New tool for stress reduction, rehabilitation and performance enhancement, HeartMath Research Center, Institute of HeartMath Boulder Creek, California, USA, 2004

8. Vaschillo E., Lehrer P., Rishe N., Konstantinov M., Heart rate variability biofeedback $\mathrm{s}$ a metod for assessing baroreflex function: A preliminary study of resonance in the cardiovascular system, APPL PSYCHOPHYS BIOF 2002; 27 (1) 1-27

9. Vaschillo E. G., Vaschillo B., Lehrer P., Characteristics of resonance in heart rate variability stimulated by biofeedback, APPL PSYCHOPHYS BIOF 2006; 31 (2) 129-142

10. Siepmann M., Aykac V., Unterdörfer J., A pilot study on effects of heart rate variability biofeedback in patients with depression and in health subjects, $A P P L$ PSYCHOPHYS BIOF 2008; 33 195-201

11. Terathongkum S., Pickler R. H., Relationships among heart rate variability, hypertension and relaxation techniques, JOURNAL OF VASCULAR NURSING 2004; 22, 78-82

12. Travinen M., Niskanen J., Kubios HRV version 2.0 User's Guide, Biosignal Analysis and Medical Imaging Group, Department of Physics, University of Kuopio, 2008
13. Dusek A., Benson H., A model of the comparative clinical impact of the acute stress and relaxation responses, MINN MED 2009; 3, 47-50

14. Krauze T., Guzik P., Wysocki H., Zmienność rytmu serca: aspekty techniczne, Nowiny lekarskie 2001; 70 (9) 973-984

15. Viola A. U., Tobaldini E., Chellappa S. L., Casali K. R., Porta A., Montano N., Short term complexity of cardiac autonomic control Turing Steep: REM as a potential risk factor for cardiovascular system in aging, PLOS ONE 2011; 6 (4) 1-8

16. Papp M., Lindfors P., Storck N., Increased heart rate variability but no effect on blond pressure from 8 weeks of hatha yoga - a pilot study, BMC RESEARCH NOTES 2013; 6 (59) 1-10

17. Xu X. Y., Gao J., Ling D., Biofeedback treatment of prehypertension: Analyses of efficiency, heart rate variability and EEG approximate entropy, $J H U M$ HYPERTENS 2007; 21, 973-975

18. Buccelletti F., Bocci M. G.,Gilardi E., Linear and nonlinear heart rate variability indexes in clinical practice, COMPUT MATH METHOD M 2012; 1 1-5

Address for correspondence:

Terespolska St. 19

PL 85-566 Bydgoszcz, Poland

Received: 12.12.2014

Accepted for publication: 17.03.2015 